\title{
Studi Viabilitas Serbuk Sari Pada Salak Bangkalan
}

\author{
Eko Setiawan \\ Prodi Agroteknologi, Fakultas Pertanian, Universitas Trunojoyo Madura \\ email: e_setiawan@trunojoyo.ac.id
}

DOI: http://dx.doi.org/10.21107/rekayasa.v12i1.5299

\begin{abstract}
ABSTRAK
Salak (Salacca zalacca) banyak dibudidayakan di Kabupaten Bangkalan. Permasalahan penyerbukan seperti kesuburan serbuk sari menjadi masalah utama dalam produksi salak di Bangkalan. Penelitian ini bertujuan untuk mempelajari viabilitas serbuk sari dari bunga jantan pada salak Bangkalan. Sampel bunga dikoleksi dari perkebunan salak di Desa Kramat, Kecamatan Bangkalan, Kabupaten Bangkalan. Pengamatan dan pembuatan preparat dilakukan di Laboratorium Produksi, Fakultas Pertanian, Universitas Trunojoyo Madura pada bulan Mei 2018. Pengamatan fertilitas serbuk sari dilakukan di bawah mikroskop setelah dilakukan pewarnaan terhadap serbuk sari dengan larutan Lugol $1 \%$. Hasil penelitian menunjukkan viabilitas serbuk sari pada bunga salak jantan kuning lebih tinggi dibandingkan dengan bunga salak jantan merah dengan perbandingan 95\% dan $10 \%$.

Kata kunci: Anther, Madura, Serbuk sari, Salacca zalacca, Steril
\end{abstract}

\section{Study on Pollen Viability of Bangkalan Snake Fruit}

\section{ABSTRACT}

Snake fruit (Salacca zalacca (Gaertner) Voss) is widely cultivated in Bangkalan District. Pollination problems such as pollen fertility are a major problem in the production of salak in Bangkalan. The objective of the study was to determine the pollen viability of Bangkalan snake fruit. Flower sample was collected from salak gardens in Kramat Village, Bangkalan and pollen analysis were conducted at the Production Laboratory, Faculty of Agriculture, the University of Trunojoyo Madura in May 2018. Observation of fertility of pollen was conducted under a microscope after pollen staining with Lugol $1 \%$. The results showed that the pollen viability of male yellow flower was higher than the red one with a ratio of $95 \%$ and $10 \%$, respectively.

Keywords: Anther, Madura, Pollen, Salacca zalacca, Sterile

\section{PENDAHULUAN}

Buah salak disebut snake fruit karena buah terbungkus kulit buah yang menyerupai sisik, dan nama ilmiahnya adalah Salacca zalacca (Gaertner) Voss (Supapvanich et al., 2011). Di Indonesia, salak banyak ditanam di Pulau Jawa (DKI Jakarta, Jawa Barat, Jawa Tengah, D.I. Yogyakarta, dan Jawa Timur), Pulau Sumatera (Lampung, Sumatera Utara, dan Sumatera Barat), dan Pulau Bali, tetapi saat ini juga dikembangkan di daerah lainnya seperti di Pulau Sulawesi, Maluku, Nusa Tenggara Barat, Pulau Kalimantan dan Pulau Madura (Zumaidar et al., 2015). Beberapa negara tetangga yang mengembangkan salak yaitu Malaysia, Filipina, Thailand, dan China Sela$\tan$ (Li et al., 2017). Bahkan di Pulau Bali, salak sudah dikembangkan sebagai tujuan wisata (Sumantra et al., 2015). Buah salak segar In-

\section{Article History:}

Received: Februari 2019; Accepted: Maret 2019

ISSN: 2502-5325 (Online) Terakreditasi Peringkat 4 oleh

Kementerian Riset, Teknologi dan Pendidikan Tinggi (ARJUNA),

berdasarkan Keputusan Direktur Jenderal Penguatan Riset dan Pengembangan Nomor: 21/E/KPT/2018 tanggal 9 Juli 2018 donesia diekspor ke beberapa negara seperti Singapura, Timur Tengah, Malaysia, Hongkong dan China (Lestari et al., 2011).

Di Pulau Madura, salak tumbuh baik di Kota Bangkalan sehingga menjadi sentra salak. Salak Bangkalan memiliki kandungan air lebih banyak dibandingkan jenis salak lainnya sehingga rasanya segar (Ariestin et al., 2015). Salak Bangkalan memiliki berbagai variasi rasa, dari rasa manis, masam, dan agak sepet; ukuran buah mulai dari sedang sampai besar, daging buahnya tebal dan berwarna putih kekuningan atau kuning kecoklatan (Maulidiah et al., 2014). Diprediksi kebutuhan buah salak akan meningkat dan berpotensi untuk dikembangkan sebagai agribisnis dan agroindustri. Buah salak selain dimakan sebagai buah segar, juga berpotensi untuk dikembangkan menjadi produk olahan pangan seperti manisan salak

\section{Cite this as:}

Setiawan, E. (2019). Studi Viabilitas Serbuk Sari Pada Salak Bangkalan. Rekayasa, 12(1), 43-48. doi:http://dx.doi.org/10.21107/ rekayasa.v12i1.5299

(C) 2019 Universitas Trunojoyo Madura 
basah, manisan salak kering, minuman segar, keripik, buah salak kaleng, dodol, permen salak, wine, asinan, cuka salak, dan yoghurt (Setianto et al., 2014; Tantrayana dan Zubaidah, 2015). Populasi tanaman salak di Bangkalan terus menurun karena (1) berkurang areal penanamannya yang beralih fungsi menjadi pemukiman, (2) tanaman sudah tua dan tidak ada peremajaan, (3) terjadi penurunan sifat akibat persilangan antara tanaman yang mempunyai hubungan kekerabatan dekat (Fatimah dan Suryawati, 2015). Salak tergolong tanaman berumah dua (dioecious), yaitu tanaman mempunyai bunga jantan atau betina terpisah dalam pohon yang berbeda, ada tanaman salak jantan dan tanaman salak betina, sehingga untuk memproduksi buah perlu bantuan penyilangan. Salak berbunga sekitar bulan Januari-Februari dan Juni-Juli. Keragaman genetik salak yang tinggi memungkinkan tanaman dikembangkan untuk memperoleh varietas unggulan (Ariestin et al., 2015). Keberhasilan peningkatan produksi buah sangat tergantung pada proses pembungaan (Sumantra dan Suyasdi, 2015). Ketidakseragaman munculnya bunga dalam satu kebun menjadi sebab lain terbatasnya produksi buah salak. Kendala utama yang dihadapi dalam pengembangan salak Bangkalan ialah kontinuitas produksi dan fluktuasi produksi antar musim panen yang besar. Hal tersebut disebabkan waktu berbunga salak dalam satu kebun tidak serempak sehingga menjadi hambatan dalam penyerbukan buatan, disamping ketersediaan serta mutu serbuk sari (pollen) yang bervariasi. Di sentra salak Bangkalan ini dikenal sekitar sebelas kultivar salak betina, dan terdapat dua jenis salak jantan yang memiliki perbedaan warna yaitu salak jantan merah dan kuning yang sering digunakan petani (Fatimah dan Suryawati, 2015; Zaed, 2015). Penelitian ini sangat penting dilakukan untuk meningkatkan produksi buah salak melalui keberhasilan proses penyerbukan. Tujuan dari penelitian ini adalah mempelajari kualitas pollen dari bunga salak jantan untuk mendukung keberhasilan pembungaan dan peningkatan produksi buah salak di Bangkalan.

\section{BAHAN DAN METODE}

Bahan yang digunakan dalam penelitian ini adalah dua jenis bunga salak jantan Bangkalan (Salacca zalacca), yaitu bunga jantan tongkol warna kuning dan warna merah sebagai perlakuan, diambil dari Desa Kramat, Kecamatan Bangkalan, Kabupaten Bangkalan. Untuk pembuatan preparat dan pengamatan dengan mikroskop dilakukan di Laboratorium Produksi, Fakultas Pertaian, Universitas Trunojoyo Madura pada bulan Mei 2018. Uji viabilitas serbuk sari dengan metoda Hair- mansis et al. (2005) masing-masing sebanyak 20 tongkol bunga jantan mekar sebagai ulangan. Pengamatan fertilitas serbuk sari dilakukan di bawah mikroskop setelah dilakukan pewarnaan terhadap serbuk sari dengan larutan Lugol 1\%. Contoh untuk serbuk sari masing-masing diambil paling sedikit dari 10 bunga dari satu tongkol atau tandan bunga jantan yang sudah mekar. Dua sampai tiga kepala sari (anther) diambil dari bunga dan ditempatkan pada kaca obyek kemudian serbuk sari ditekan hingga keluar menggunakan pinset dalam larutan Lugol 1\%. Serbuk sari yang layu dan tidak terwarnai (unstained withered, unstained spherical) atau terwarnai sebagian (partially stained round) dikelompokkan sebagai serbuk sari steril, sedangkan yang berwarna (stained round) merupakan serbuk sari yang fertil. Viabilitas (\%) serbuk sari dihitung dengan menjumlah serbuk sari yang berwarna dibagi dengan seluruh serbuk sari yang diamati dikalikan 100. Pengamatan dilakukan dengan menggunakan mikroskop Olymphus. Hairmansis et al. (2005), berdasarkan persentase fertilitas serbuk sarinya genotipe dikelompokkan sebagai fertil $(F=$ fertile, $60-100 \%)$, fertil sebagian ( $P F=$ partially fertile, $30-60 \%$ ), steril sebagian (PS = partially sterile, $1-30 \%$ ) dan steril penuh (CS = completely sterile, 0\%). Apabila uji $\mathrm{F}$ menunjukkan perbedaan perlakuan nyata, maka dilanjutkan dengan uji BNT.

\section{HASIL DAN PEMBAHASAN}

Studi tentang sterilitas serbuk sari merupakan cara yang sangat baik untuk memahami mekanisme molekuler pada proses reproduksi seksual bunga salak jantan di Bangkalan. Sterilitas pada serbuk sari disebabkan oleh berbagai hal, diantaranya anther tidak mampu pecah/terbuka sehingga memiliki efek pada produktivitas dan mengurangi hasil panen secara signifikan. Ciri morfologi tandan atau tongkol bunga jantan kuning yaitu mempunyai panjang $\pm 14 \mathrm{~cm}$. Bunga jantan kuning mempunyai ukuran tandan lebih besar dan semua bunga membuka sempurna dari pangkal sampai ke ujung (Gambar 1a). Warna kuning yang nampak pada pada permukaan tongkol sebenarnya adalah serbuk sari yang pecah dari kepala sari (anther) sehingga masyarakat menyebutnya sebagai bunga jantan kuning (Gambar 2a). Bunga jantan merah mempunyai panjang tongkol $\pm 9 \mathrm{~cm}$ (Gambar $1 b$ ). Berbeda dengan bunga jantan kuning yang berkembang sempurna, sekitar 0.25 $0.33 \%$ bagian ujung dari tandan bunga jantan merah tidak berkembang atau tidak membuka sempurna dan permukaan anther mengering. Anther yang tidak pecah menyebabkan tongkol atau tandan bunga terlihat dominan berwarna merah dari kelopak bunga saja, 


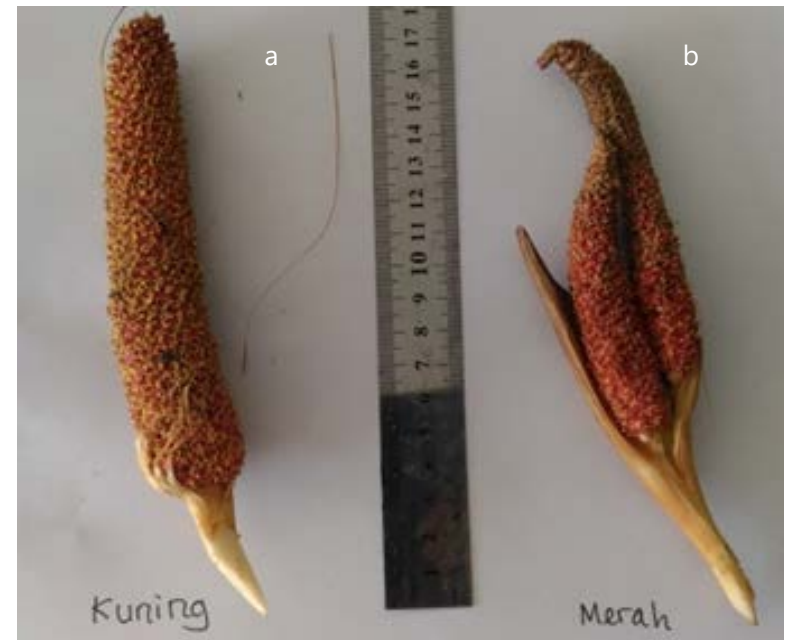

Gambar1. Tandan atau tongkol bunga salak jantan, kiri bunga salak jantan kuning dan kanan bunga salak jantan merah

sehingga masyarakat mengenalnya sebagai bunga jantan merah (Gambar 2b). Bunga salak jantan Bangkalan warna kuning dan warna merah dilaporkan Fatimah dan Suryawati (2015) mempunyai indeks similaritas sebesar $80 \%$.

Penyerbukan salak terjadi dengan bantuan angin, serangga dan manusia. Penyerbukan dengan bantuan angin hasilnya lebih rendah bila dibandingkan dengan penyerbukan bantuan manusia atau serangga. Hal ini karena benang sari dari bunga salak mempunyai sifat lengket sehingga tidak mudah diterbangkan oleh angin. Saat yang terbaik serbuk sari dari bunga jantan dipergunakan untuk penyerbukan yaitu ketika bunga jantan mekar dan mengeluarkan serbuk warna kuning. Penyerbukan salak di Bangkalan dibantu oleh manusia, yaitu dengan cara memukul-mukulkan bunga jantan yang telah dipotong ke bunga betina yang sedang mekar (Mogea, 1979). Penyerbukan pada salak bisa dibantu oleh serangga moncong Curculionidae (Gambar 2a). Bantuan penyerbukan oleh manusia dapat meningkatkan fruit-set (Supapvanich et al., 2011).

Pada Gambar 3 menunjukkan ukuran individu bunga salak jantan kuning lebih besar atau panjang dibandingkan dengan salak jantan merah baik sebelum maupun sesudah bunga mekar (anthesis). Setelah bunga mekar (Gambar 3c) pada bunga salak jantan kuning tumbuh memanjang dibandingkan dengan salak jantan merah (Gambar 3d). Pecahnya anther merupakan langkah penting dalam anthesis yang menghasilkan pelepasan serbuk sari matang; terkoordinasi dengan bunga mekar, diferensiasi dan pematangan serbuk sari, serta pemanjangan filamen (Xiao et al., 2014).

Dinding anther pada bunga salak jantan kuning pecah dan mengeluarkan serbuk sari
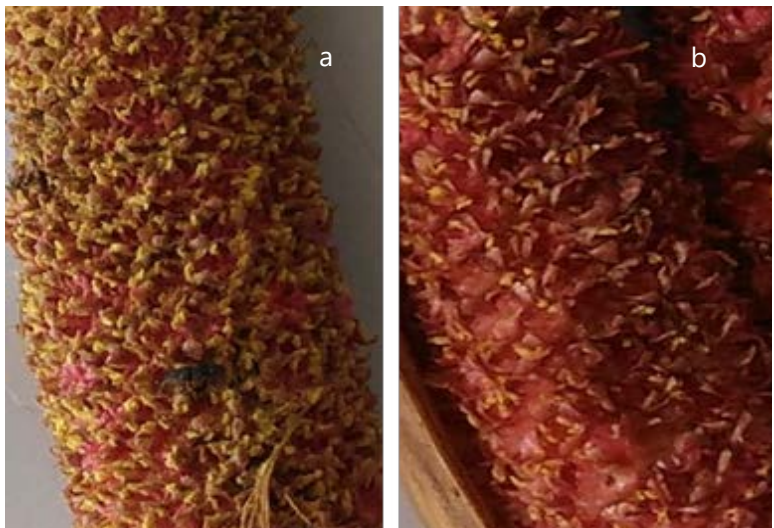

Gambar 2. Tandan atau tongkol bunga salak jantan sudah membuka, (a) bunga jantan kuning mengeluarkan serbuk sari dan terlihat kumbang moncong aktif mendatangi (b) bunga salak jantan merah kondisi serbuk sari banyak yang kering.
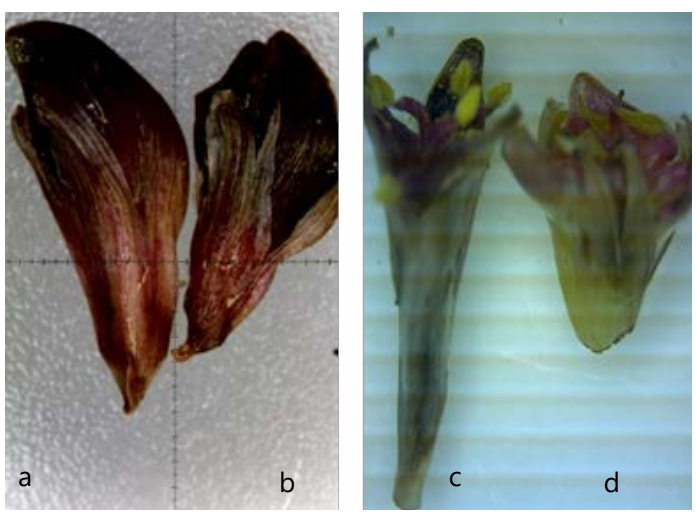

Gambar 3. Gambar individu bunga salak jantan (a) bunga salak jantan kuning masih belum membuka, (b) bunga salak jantan merah masih belum membuka, (c) bunga salak jantan kuning sudah membuka, anther pecah dan mengeluarkan serbuk sari, dan (d) bunga salak jantan merah membuka tetapi anther tidak pecah dan serbuk sari tidak dihasilkan.
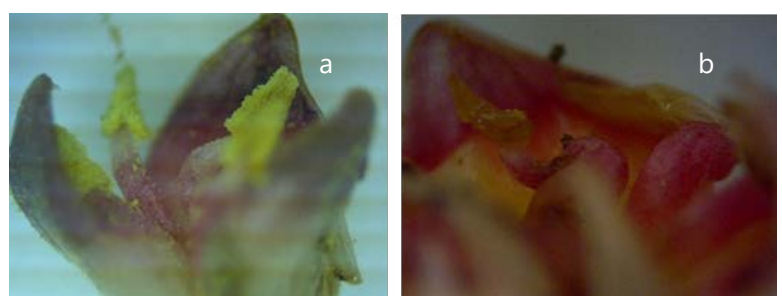

Gambar 4. Anther pecah dan mengeluarkan serbuk sari pada bunga salak jantan kuning

(a), dan anther kering pada bunga salak jantan merah (b).

yang berhamburan sebagai tanda siap untuk menyerbuki (Gambar 4a). Xiao et al. (2014) pecahnya anther disebabkan oleh hilangnya air dari dinding anther serta adanya tekanan oleh serbuk sari membengkak, terpelintir dan sel-sel kelompok melingkar terbelah dan berikutnya pelepasan serbuk sari. Dinding anther yang berhasil pecah atau terbuka, proses yang 
sangat penting adalah waktu pecah/terbuka, terbentuk penebalan dinding sekunder, degenerasi berbagai jaringan anther, perubahan dalam metabolisme karbohidrat dan pergerakan air keluar dari anther (Thangasamy et al., 2011).

Pada Gambar 4b adalah bunga salak jantan merah sudah mekar, tetapi dinding anther tidak pecah, permukaannya mengering dan berwarna agak gelap. Hal tersebut diduga akibat serbuk sari dari bunga salak jantan merah bersifat steril, tidak berkembang dan tidak mampu mendorong pecahnya dinding anther, sehingga tidak dihasilkan serbuk sari untuk penyerbukan. Klaster sel sirkuler pada dinding anther yang tidak pecah (pada bunga salak jantan merah), kondisinya masih utuh meskipun dinding anther menyusut jauh (Xiao et al., 2014). Gelapnya warna permukaan anther yang diamati pada bunga jantan merah (Gambar 4b) mungkin disebabkan oleh akumulasi senyawa fenolik, seperti yang dilaporkan pada Piper vicosanum (Valentin-silva et al., 2018). Kriswiyanti et al. (2008) penyebab serbuk sari steril antara lain adalah serbuk sari yang dibentuk normal tetapi tidak dilepaskan karena dinding anther tidak pecah, anther tertekan, gugur, berbentuk pipih menyerupai daun. Pada anther yang tidak membuka, selsel epidermis dari bunga jantan mengalami dehidrasi dan menunjukkan kutikula sedikit lurik dan menjadi pucat, dinding anther terdiri dari sel-sel epidermal yang kering (Zini et al., 2012)

Manifestasi fenotipik dari male-sterility sangat beragam, mulai dari tidak adanya organ jantan, kegagalan untuk mengembangkan jaringan sporogenous normal, aborsi serbuk sari dalam beberapa tahap perkembangannya, tidak adanya pembukaan stamen, dan ketidakmampuan serbuk sari untuk berkecambah pada stigma yang sesuai (Zini et al., 2012). Hasil ini menunjukkan bahwa bunga salak jantan merah bersifat steril dan jika digunakan dalam penyerbukan maka akan terjadi kegagalan fruit-set dan dapat menurunkan produksi buah. Penyerbukan sebaiknya menggunakan bunga salak jantan kuning. Untuk optimalisasi penyerbukan, perbandingan ratio tanaman dalam satu areal kebun sebaiknya yaitu 20-50 tanaman salak betina berbanding 1 tanaman jantan (Li et al., 2017).

Pada Gambar 5 menunjukkan serbuk sari (pollen) bunga salak jantan yang diperlakukan dengan larutan Lugol 1\%, yang fertile ditandai dengan terwarnai sedangkan yang steril tidak terwarnai. Persentase serbuk sari fertil pada bunga salak jatan kuning mencapai $95 \%$, sedangkan pada bunga salak jantan merah hanya sekitar 10\% (Tabel 1). Kriswiyanti
Tabel 1. Persentase serbuk sari fertil dan steril pada bunga salak jantan

\begin{tabular}{ccc}
\hline $\begin{array}{c}\text { Jenis bunga salak } \\
\text { jantan }\end{array}$ & $\begin{array}{c}\text { Serbuk sari fertil } \\
(\%)\end{array}$ & Klasifikasi (1) \\
\hline Bunga Kuning & $95 \mathrm{~b}$ & $\mathrm{~F}$ \\
Bunga Merah & $10 \mathrm{a}$ & $\mathrm{PS}$ \\
\hline
\end{tabular}

(1) $F($ fertile) $=$ Serbuk sari $60-100 \%$; PF (partially fertile) $=30$ $60 \%$; PS (partillly sterile $)=1-30 \%$; CS $($ completely sterile $)=0$

et al. (2008) pada salak Bali viabilitas serbuk sari sekitar $71.4 \%$ pada anther tidak pecah, hal ini mungkin disebabkan serbuk sari memang sudah masak namun anther belum pecah. Hasil penelitian menunjukkan pada bunga salak jantan merah viabilitas serbuk sarinya rendah dan sebagian besar bersifat steril yang diindikasikan oleh serbuk sari yang tidak terwarnai (Gambar 5b). Serbuk sari steril dapat juga disebabkan oleh ketidakseimbangan genetis yang terjadi pada saat produksi gamet (Kriswiyanti et al., 2008). Pada Gambar $5 d$ menunjukkan bahwa pada bunga salak jantan merah dinding anther tidak pecah dan serbuk sari steril (tidak terwarnai) saling menempel atau lengket di dalam. Zini et al. (2012) male-sterility disebabkan oleh perkembangan tapetum abnormal dan pembentukan exine tidak teratur; formasi exine tidak teratur dikaitkan dengan degenerasi dini dari sel-sel tapetal pada pembelahan meiosis pertama microspores mother cells. Viabilitas serbuk sari salak Bangkalan Madura dilaporkan turun menjadi $35.16 \%$ setelah disimpan dalam eksikator selama 8 minggu (Kriswiyanti et al., 2008). Perilaku tapetum dan kematian terprogram pada bunga Melicoccus lepidopetalus (Sapindaceae) mungkin telah menyebabkan struktur serbuk sari abnormal dan terjadi aborsi serbuk sari (Zini et al., 2012).

Perkembangan bunga pada tanaman dikendalikan oleh gabungan dari faktor genetik dan lingkungan. Secara genetik, gen PhERS1 dan PhETR2 mengatur sinkronisasi pecahnya dinding anther dengan waktu bunga mekar (Thangasamy et al., 2011). Pada tanaman kapas, tahap perkembangan anther berhubungan dengan vigortas pollen yang melibatkan beberapa ekspresi gen seperti GhCK1, PIF dan gen dalam jalur gula dan auksin terkait dengan perkembangan anther di bawah tekanan panas (Song et al., 2015).

Faktor lingkungan, terutama suhu dapat mempengaruhi ekspresi gen male-sterility (Ma et al., 2013). Pada fase pertumbuhan hypersensitive tanaman pada kondisi suhu di atas $36{ }^{\circ} \mathrm{C}$ dapat menyebabkan perkembangan anther dan pollen menjadi tidak normal (Bernhard et al., 2017). Suhu kebun salak yang ideal yaitu sekitar $26.2^{\circ} \mathrm{C}$ dengan kelembaban 

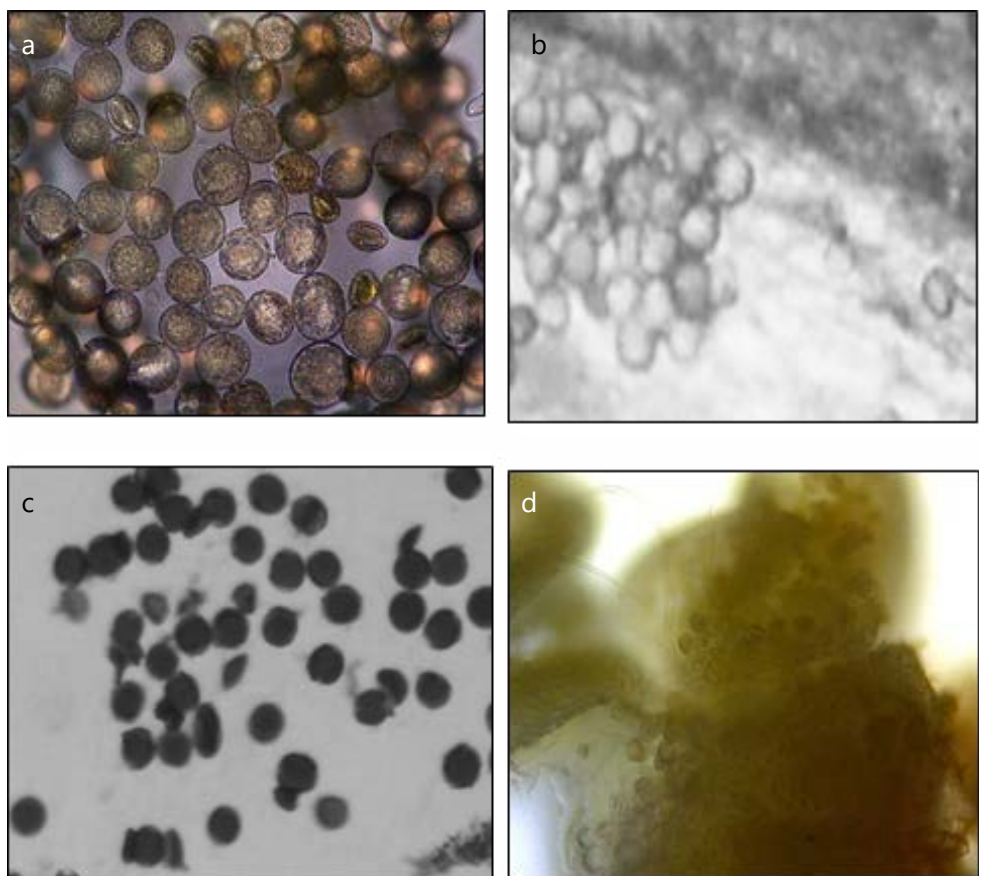

Gambar 5. Serbuk sari bunga salak yang diberi larutan Lugol 1\% di bawah mikroskop (a) Serbuk sari asal bunga jantan kuning yang fertil (terwarnai) dengan perbesaran $400 \times$ dan (b) serbuk sari asal bunga jantan merah yang steril (bagian yang tidak terwarnai) dengan perbesaran $400 \times$ (c) Serbuk sari asal bunga jantan kuning yang fertil (terwarnai) dengan perbesaran $100 \times$ dan (d) anther bunga jantan merah tidak pecah sehingga serbuk sari steril (bagian yang tidak terwarnai) terlihat di bawahnya dengan perbesaran 100x.

74\% (Mogea, 1979); suhu di Bangkalan di pagi hari sekitar $27.8^{\circ} \mathrm{C}$ dengan kelembaban sebesar $88.7 \%$, sedangkan pada siang hari suhunya meningkat $\pm 33.3^{\circ} \mathrm{C}$ atau lebih dan kelembabannya turun menjadi 72\% (Setiawan, 2017). Sterilitas pada bunga salak jantan merah diduga disebabkan oleh faktor suhu yang tinggi di Bangkalan, sementara dari sisi genetik perlu dilakukan investigasi lebih lanjut. Pada Vigna unguiculata L., dinding anther gagal membuka pada suhu $33^{\circ} \mathrm{C}$ karena tanaman mengalami stress panas (Devasirvatham et al., 2012). Penurunan fruit-set terjadi disebabkan oleh male-sterility akibat suhu meningkat dari 30 ${ }^{\circ} \mathrm{C}$ hingga $35^{\circ} \mathrm{C}$ (Wiebbecke et al., 2012). Suhu tinggi akan menurunkan kesuburan serbuk sari dan terjadi kelainan, ukuran pollen menjadi kecil dan kosong; suhu malam yang hangat $\pm 28{ }^{\circ} \mathrm{C}$ juga dapat mengurangi produksi serbuk sari (Devasirvatham et al., 2012). Song et al. (2015) sensitivitas terhadap suhu tinggi menyebabkan viabilitas pollen pada kapas turun drastis terutama pada tiga stage yaitu fase I (sporogenous cell), fase II pollen mother cell (PMC meiosis) dan fase III (tetrad stage). Khususnya pada tahap I-III tersebut, anther tidak dapat pecah/terbuka meskipun bunga sudah mekar, butir serbuk sari tidak normal dan persentase pollen yang berkecambah adalah nol (Song et al., 2015).
Fitohormon seperti asam jasmonate (JA) memainkan fungsi penting dalam reproduksi tanaman seperti kesuburan serbuk sari, penentuan jenis kelamin dan pematangan benih (Yuan and Zhang, 2015). Sinha and Rajam (2013) level poliamine berkaitan erat dengan male-sterility terutama untuk perkembangan serbuk sari (pollen). Rai et al. (2010) tinggi rendahnya persentase fruit-set pada salak Gula Pasir disamping dipengaruhi oleh kandungan IAA pada daun dan bunga, juga berkaitan dengan kandungan gula total dan gula reduksi pada daun. Persentase fruit-set pada tanaman salak juga dipengaruhi oleh kandungan air relatif pada daun, jumlah curah, serta jumlah hari hujan (Rai et al., 2010). Kandungan gula total dan gula reduksi daun yang rendah menunjukkan kemampuan daun tersebut untuk menyokong perkembangan bunga kurang optimal sehingga menyebabkan bunga gugur atau gagal mengalami fruit-set.

\section{KESIMPULAN}

Dengan uji warna, viabilitas serbuk sari pada bunga salak jantan kuning lebih tinggi dibandingkan dengan bunga salak jantan merah dengan perbandingan $95 \%$ dan $10 \%$. Untuk menjamin keberhasilan penyerbukan dan meningkatkan produksi salak di Kabupaten Bangkalan sebaiknya digunakan bunga salak jantan kuning. 


\section{DAFTAR PUSTAKA}

Ariestin, Y., Kuswanto, S. Ashari. 2015. Keragaman jenis salak Bangkalan \{Salacca zalacca (Gaertner) Voss\} menggunakan penanda morfologi dan analisis ISOZIM. J. Produksi Tanam. 3(1): 35-42.

Bernhard, T., W. Friedt, R.J. Snowdon, B. Wittkop. 2017. New insights into genotypic thermodependency of cytoplasmic male sterility for hybrid barley breeding. Plant Breed. 136: 8-17.

Devasirvatham, V., P.M. Gaur, N. Mallikarjuna, R.N. Tokachichu, R.M. Trethowan, D.K.Y. Tan. 2012. Effect of high temperature on the reproductive development of chickpea genotypes under controlled environments. Funct. Plant Biol. 39: 1009-1018.

Fatimah, S., S. Suryawati. 2015. Uji kekerabatan antara salak jantan dan salak betina (Salacca zalacca (Gertner) Voss) Bangkalan. Agrovigor 8(2): 39-45.

Hairmansis, A., H. Aswidinnoor, Tirkoesoemaningtyas, Suwarno. 2005. Identification of wide compatibility varieties in some tropical Japonica rice. Indones. J. Agric. Sci. 6(1): 28-31.

Kriswiyanti, E., I.K. Muksin, L. Watiniasih, M. Suartini. 2008. Pola reproduksi pada salak Bali (Salacca zalacca Var. Amboinensis (Becc.) Mogea. J. Biol. 11(2): 78-82.

Lestari, R., G. Ebert, S. Huyskens-Keil. 2011. Growth and physiological responses of salak cultivars (Salacca zalacca (Gaertn.) Voss) to different growing media. J. Agric. Sci. 3(4): 261-271.

Li, R., J. Li, G. Yin, J. Yang, W. Zou, L. Bai. 2017. A male-specific SCAR DNA marker and sex ratio of seedlings in salak (Salacca zalacca var. zalacca). J. For. Res. 28(1): 47-50.

Ma, Y., W. Huang, J. Ji, Z. Gong, C. Yin, S.S. Ahmed, Z.-L. Zhao. 2013. Maintaining and restoring cytoplasmic male sterility systems in pepper (Capsicum annuum L.). Genet. Mol. Res. 12(3): 2320-2331.

Maulidiah, A., D. Hidayati, S. Hastuti. 2014. Analisa karakteristik manisan kering salak (Salacca edulis) dengan lama perendaman dan konsentrasi larutan gula. Agrointek 8(1): 23-31.

Mogea, J.P. 1979. Faktor musim dalam pembuahan salak (Salacca edulis). Ber. Biol. 2(4): 71-74.

Rai, I.N., C.G.A. Semarajaya, I.W. Wiraatmaja. 2010. Studi fenofisiologi pembungaan salak gula pasir sebagai upaya mengatasi kegagalan fruit-set. J. Horti 20(3): 216-222.

Setianto, Y.C., Y.B. Pramono, S. Mulyani. 2014. Nilai $\mathrm{pH}$, viskositas, dan tekstur yoghurt drink dengan penambahan ekstrak salak pondoh (Salacca zalacca). Apl. Teknol. Pangan 3(3): 110-113.

Setiawan, E. 2017. Efektivitas pemberian IAA, IBA, NAA, dan Root-up pada pembibitan kesemek. J. Hort. Indones. 8(2): 97-103.
Sinha, R., M.V. Rajam. 2013. RNAi silencing of three homologues of S-adenosylmethionine decarboxylase gene in tapetal tissue of tomato results in male sterility. Plant Mol. Biol. 82: 169-180.

Song, G., M. Wang, B. Zeng. 2015. Anther response to high-temperature stress during development and pollen thermotolerance heterosis as revealed by pollen tube growth and in vitro pollen vigor analysis in upland cotton. Planta 241(5): $1271-1285$.

Sumantra, I.K., I.N.L. Suyasdi. 2015. Pembuahan salak gulapasir di luar musim berkualitas standar salak Indonesia. Bakti Sar. 4(1): $64-72$.

Sumantra, I.K., A. Yuesti, K. Sudiana. 2015. Pengembangan model agrowisata salak berbasis masyarakat di desa Sibetan. Bakti Sar. 4(2): 156-168.

Supapvanich, S., R. Megia, P. Ding. 2011. Salak (Salacca zalacca (Gaertner) Voss). Postharvest Biology and Technology of Tropical and Subtropical Fruits. Woodhead Publishing Limited.

Tantrayana, P.B., E. Zubaidah. 2015. Karakteristik fisik-kimia dari ekstrak salak gula pasir dengan metode maserasi. J. Pangan Agroindustri 3(4): 1608-1619.

Thangasamy, S., C. Guo, M. Chuang, M. Lai, J. Chen, G. Jauh. 2011. Rice SIZ1, a SUMO E3 ligase, controls spikelet fertility through regulation of anther dehiscence. New Phytol. 189: 869-882.

Valentin-silva, A., M.A. Batalha, E. Guimarães. 2018. Dynamics of pollen release and stigmatic exposure in neotropical Piper species: a possible pattern for the genus. Int. J. Plant Sci. 179(4): 287-295.

Wiebbecke, C.E., M.A. Graham, S.R. Cianzio, R.G. Paltner. 2012. Day temperature influences the male-sterile locus ms9 in soybean. Crop Sci. 52: 1503-1510.

Xiao, Y. Y. Chen, T. Charnikhova, P.P.J. Mulder, J. Heijmans, A. Hoogenboom, P.B.F. Ouwerkerk. 2014. OsJAR1 is required for JA-regulated floret opening and anther dehiscence in rice. Plant Mol. Biol. 86(12): 19-33.

Yuan, Z., D. Zhang. 2015. Roles of jasmonate signalling in plant inflorescence and flower development. Curr. Opin. Plant Biol. 27: 44-51.

Zaed, A.S. 2015. Pengaruh perbedaan sumber polen dan varietas salak (Salacca zalacca Gaertner Voss.) terhadap kualitas buah. Agrovigor 8(1): 51-57.

Zini, L.M. G.B. Galati, S.M. Solís, M.S. Ferrucci. 2012. Anther structure and pollen development in Melicoccus lepidopetalus (Sapindaceae): an evolutionary approach to dioecy in the family. Flora 207(10): 712-720.

Zumaidar, T. Chimawati, A. Hartana, Sobir. 2015. Keanekaragaman genetik Salacca zalacca berdasarkan penanda AFLP. Floribunda 5(2): 60-70. 